\title{
Private International Law as an Ethic of Responsivity
}

\author{
Ralf Michaels*
}

\section{Introduction}

The world is a mess. Populism, xenophobia, and islamophobia; misogyny and racism; the closing of borders against the neediest—-the existential crisis of modernity calls for a firm response from ethics. Why, instead of engaging with these problems through traditional ethics, worry about private international law, that most technical of technical fields of law? My claim in this chapter: not despite, because of its technical character. Private international law provides such an ethic, an ethic of responsivity. It provides us with a technique of ethics, a technique that helps us conceptualise and address some of the most pressing issues of our time. It is not only ethically relevant, it is itself an ethic. Let me explain.

\section{Private International Law and Ethics}

Whether private international law has an ethical dimension is a question that has long been discussed. ${ }^{1}$ On one level, the relevance should be obvious. First, private

\footnotetext{
* Arthur Larson Professor of Law, Duke University. This is the expanded written version of my keynote address at the Edinburgh Conference entitled "Private International Law: Embracing Diversity.” I thank Verónica Ruiz Abou-Nigm and María Blanca Noodt Taquela for the invitation and participants for a lively and very helpful discussion.

${ }^{1}$ The most comprehensive such project, one that has influenced the argument in this chapter, is Muir Watt, H. (2017) 'Hospitality, Tolerance, and Exclusion in Legal Form:
} 
international law decisions often have to grapple with the ethical challenges listed above; indeed, it is often in private international law cases that these issues come up concretely. Xenophobia and populism regularly occur as refusals to apply foreign law (even though the reverse is not true: such refusals are not necessarily evidence of xenophobia). ${ }^{2}$ Islamophobia in particular frequently appears as "shariaphobia”, fear of Islamic law, and thus in the context of private international law. The backlash against the Archbishop of Canterbury's proposal to give Islamic law a place in Britain is one example; another are the foreign law amendments and laws in the United States, which ostentatiously ban courts from applying any foreign law but are really mostly directed against the application of Islamic law. ${ }^{3}$ Misogyny and racism are both issues for private

Private International Law and the Politics of Difference', Current Legal Problems, Vol. 70, No. 1, 111-147 (hereinafter Muir Watt, 'Politics of Difference’ (2017)); Muir Watt, H. (2018) 'Discours sur les méthodes du droit international privé (des formes juridiques de l'inter-altérité)', Recueil des Cours, Vol. 389. See also, e.g., some of the contributions in D. E. Childress III (ed.) (2012), The Role of Ethics in International Law, Cambridge University Press.

${ }^{2}$ See also Clermont, K. M. \& T. Eisenberg, (2007) 'Xenophilia or Xenophobia in American Courts? Before and After 9/11', 4 Journal of Empirical Legal Studies, 441464.

${ }^{3}$ On the former, see Griffith-Jones, R. ed., (2013) Islam and English Law, Cambridge University Press . On the latter, see Fellmeth, A. (2012) 'U.S. State Legislation to Limit Use of International and Foreign Law’, 106 Am. J. Int'l L. 107; Volokh, E., (2014), 'Religious Laws (Especially Islamic Law) in American Courts', 66 Okla. L. Rev., and, for a broader reading of foreign law bans as directed not just against Islamic law but against foreign law in general, Rahdert, M.C. (2016) 'Exceptionalism Unbound: Appraising American Resistance to Foreign Law', 65 Cath. U. L. Rev. 537. 
international law, especially where feminism and multiculturalism come to a clash in view of a foreign law that discriminates against women. ${ }^{4}$

Second, even where such ethical challenges are discussed without reference to private international law, private international law often remains relevant. Take, as an important example, the current refugee crisis. Numerous questions related to itwhether a refugee's child marriage should be recognized, what the refugee's domicile is, and so forth—concern, at heart, issues of private international law. Moreover, even the refugee's status itself is, to a considerable extent, a question of private international law, in accordance with what Karen Knop has called private citizenship. ${ }^{5}$ It goes largely unrecognised (though it ought not to) that Hannah Arendt, when she discusses the famous "right to have rights" as a defence of refugee rights, uses a private international law example to make her point: “a German citizen under the Nazi regime might not be able to enter a mixed marriage abroad because of the Nuremberg laws.” ${ }^{6}$ Private international law is present even where it is not recognised.

${ }^{4}$ See Knop, K., R. Michaels \& A. Riles, (2012) 'From Multiculturalism to Technique: Feminism, Multiculturalism, and the Conflict of Laws Style’, 64 Stan. L. Rev. 589; for a feminist approach, see also Banu, R. (2017) 'A Relational Feminist Approach to Conflict of Laws', 24 Michigan Journal of Gender and Law, 1.

${ }^{5}$ Knop, K. (2008) ‘Citizenship, Public and Private’, 71 L. \& Contemp. Probs. 309. In French law, the law of aliens is part of private international law.

${ }^{6}$ Arendt, H. (1994) The Origins of Totalitarianism, Schocken Books, 294. For the historical background, see, e.g., Caestecker, F. and D. Fraser (2008), 'The Extraterritorial Application of the Nuremberg Laws. Rassenschande and Mixed Marriages in European Liberal Democracies', 10 J. Hist. Int'l L. 35. 


\section{A. Three Positions against Ethics}

If, therefore, private international law is somehow related to questions of ethics, a direct importance is nonetheless often denied. Three positions can be separated, each related to one term in the discipline's name: private, international, law. Because it is international, it is considered incapable of dealing with ethical questions. Because it is private, it is considered irrelevant to questions of ethics. And because it is law, more precisely: technical law, it is considered inadequate. Each of these critiques shall be briefly discussed in turn.

The first position is that private international law, as an international technical discipline, is incapable of dealing with matters of private international law. Understood as a discipline that merely allocates substantive and ethical decisions to the proper sovereign - whether based on comity, the seat of a legal relation, or the closest connection—private international law wears a "blindfold" with regard to the ethical content of these laws themselves. Private international law in this sense is ethically “neutral.”

Among those who hold this view, differences exist as to what a proper response would be. While some support such neutrality, others believe that ethical concerns must be taken seriously within private international law. A narrower response is to use the public policy exception as an "ethical moment,"7 the application of substantive and ethical ideas to avoid application of a law that had been designated as applicable before without consideration to its substance. A broader response is to replace the technical

\footnotetext{
${ }^{7}$ Knop et al. (2012), above fn 4, at 640-42.
} 
conflict of laws altogether with a method that focuses on the "real conflicts" which are, in principle, substantive conflicts. ${ }^{8}$

A second position is that private international law is irrelevant because it deals with small questions without ethical relevance. For this perspective, ethical questions are, by contrast, big questions and are, as such, the business of public, not private, international law. Robert Wai could be understood to hold such a view when he says that

"[w]ar and depression, the twin nightmares of public international lawyers and international trade lawyers ... are not the overriding concerns of private international law. Private law conflicts are instead disputes among private parties about a defective product, an accident, or a violated contract. Focusing away from the extremes of international anarchy permits a calmer view of the role of contestation and dissensus." 9

Even granting that war and depression are the more important ethical issues, private international law is related to these issues as well: it has long (though intermittently) been discussed as a response to the enmity that spurs war, ${ }^{10}$ and it deals with those trade

${ }^{8}$ Singer, J. W. (1989) 'Real Conflicts’, 69 B.U. L. Rev. 1, 74ff.

${ }^{9}$ Wai, R. (2005) 'Transnational Private Law and Private Ordering in a Contested Global Society', 46 Harv. Int'l L.J. 471, 472-3.

${ }^{10}$ Schulze, G. (2016) 'Die Überwindung von Feindschaft durch Kollisionsrecht-Ein Grundgedanke des Internationalen Privatrechts von der Antike bis zu seiner Vergemeinschaftung in Europa' in Strangas et al. (eds), Kollision, Feindschaft und Recht, Nomos, 1097-1128; see also Spain, A. (2013), 'International Dispute Resolution in an Era of Globalization' in A. Byrnes, M. Hayashi and C. Michaelsen (eds.), International Law in the New Age of Globalization, Martinus Nijhoff, 41, 68-69. The Hague Academy of International Law, was explicitly set up as an instrument for the 
relations that make up the financial markets and thus can contribute to depression. ${ }^{11}$ But it seems questionable already whether the core issues of private international law are really less relevant from an ethical perspective, merely because they (often) deal with fewer individuals. Ethics is relevant in the particular, the concrete.

A third position is that private international law, at least in its traditional form, is inadequate to deal with questions of private international law because it is technical. In this realm, Joel Paul deplores the isolation of private international law from public international law (and therefore from politics), ${ }^{12}$ and Horatia Muir Watt criticises private international law for its "epistemological tunnel-vision, actively providing immunity and impunity to abusers of private sovereignty."13 These authors, and likeminded others, do not think of private international law as intrinsically incapable of dealing with ethical questions, but they think that it is in its current form. They ask us, in other ways, to rethink private international law fundamentally, in order to move it from a technical to a political understanding.

promotion of peace through law; it fulfills this in part through courses in both public and private international law. Nonetheless, public international lawyers tend to ignore the role of private international law; it is absent, e.g., from Bailliet, C. M. and K. Mujezinovic Larsen (eds.), (2015) Promoting Peace Through International Law, Oxford University Press.

11 See Riles, A. (2014) 'Managing Regulatory Arbitrage: A Conflict of Laws Approach', 47 Cornell Int'l L.J. 63.

12 Paul, J. R. (1988) ‘The Isolation of Private International Law’, 7 Wis. J. Int’l L. 149, 164ff; see also Paul, J. R. (2008) 'The Transformation of International Comity’, 71 L.\&Contemp. Probs. 19.

13 Muir Watt, H. (2011) 'Private International Law Beyond the Schism' 2 Transnational Legal Theory 347, 374. 


\section{B. The Other in Private International Law}

Against all these critiques, how do we get at the ethical dimension of private international law? Think of what ethics is about at its core: it is about our relation to the Other. ${ }^{14}$ Ethics may be, abstractly, the discipline of right and wrong, but most of that is focused on how we should "do unto others," on our relation with an Other. This Other is a fascinating concept. “Je est un autre,” says Rimbaud famously, 'I is an Other,' and though here the focus is more on the I than on the Other, the quote expresses very well the complex dual nature of the Other in relation to the self. The Other is like me in that she is another sentient being. And the Other is unlike me because she is different, an Other. She is both, me and not me. My relation to the Other involves me as an actor, but it also involves me in the Other: how I relate to the Other says something about me, it says something about how I relate to me.

This should suggest how private international law is related to ethics. Let us leave aside, for a moment, both its specific doctrines and tools - its technical character-and its ultimate goals - its results that are usually discussed when questions of ethics and politics are at stake. Let us instead focus on the core situation that private international law addresses. In private international law, we deal with something foreign: a foreign party, a foreign contact, a foreign law. We do not face the 'normal' case in which law, parties, facts, all belong to the same order; we have to relate our normative order to this

\footnotetext{
${ }^{14}$ On this theme, see, e.g., Waldenfels, B. (2007), The Question of the Other, State University of New York Press.
} 
foreign element. We deal, then, with an Other. ${ }^{15}$ That Other can be a foreign law, it can be a foreign party, or it can be another foreign element. But insofar as a foreign element is necessary to trigger a meaningful conflict of laws analysis, the foreign, the Other, is a constant of private international law regardless of what else one thinks the discipline is about.

Is however, the foreign element that triggers a conflict of laws analysis an Other in the sense of ethics? Conflict of laws deals with foreign laws; ethics deals with personsare those the same thing? It is not necessary to think we have ethical obligations towards foreign law, as Pierre Legrand has frequently argued: ${ }^{16}$ our ethical obligations are towards people, not laws. But laws matter only insofar as they apply to people, and people in return come with laws. This means that treating people and treating laws are interrelated: our treatment of foreign law is our treatment of people. The Afghani couple that comes to our court carries with it the laws under which it got married. A refusal to apply that law (or recognise their marriage under that law) concerns not only, not even primarily the law, but instead the persons who rely on it. Our attitude towards the law under which a contract was formed is closely related to the contract itself and thereby to the persons who entered into that contract and who constituted their interrelation, and thus their identity, through it.

${ }^{15}$ Berman, P. S. (2010) 'Conflict of Laws and the Negotiation of Difference', in A. D. Sarat, M. Umphrey \& L. Douglas (eds.), Law and the Stranger, Stanford University Press, 141, 143ff.

${ }^{16}$ E.g. Legrand, P. (2012) 'Foreign Law in the Third Space', juridikum 32. 


\section{Three Attitudes}

Foreign law is, then, like the Other: similar and different at the same time. Foreign law is similar because it is law, just like the law of the forum is law. Foreign law is different because it is foreign law, not the law of the forum. If this is correct, then one minimum ethical demand within private international law is to acknowledge this situation of the other as both different and similar to us. Such acknowledgment is denied both where difference is denied and where similarity is denied.

Denial of difference is the easier variant. It occurs where the law of the forum is applied as a matter of course (lex fori approach), regardless of the foreign element involved in a fact pattern, because it is assumed that the foreign element is in all relevant regards similar to the local elements that domestic law has in mind. In this case the law ignores that the plaintiff before the court is a foreigner; it ignores that the tort before the court occurred elsewhere; it ignores that the intentions of the parties to the contract were built against background expectations different from those existing in the forum's state. If there were no private international law, then difference would always be denied, and that would be unethical. It is through private international law that it is acknowledged. Similarity, by contrast, is denied where foreign law is rejected tout court, without specific consideration of how it plays out in the concrete context. The foreign law amendments in the United States and the English aversion to Islamic law, mentioned before, are one example of such fundamental rejection. They are based on the idea of fundamental otherness. We find this idea of fundamental otherness especially vis-à-vis 
religious laws. ${ }^{17}$ But the idea goes beyond this where American exceptionalism is invoked to justify a fundamental otherness of any foreign law as a reason for its irrelevance. That would be unethical in its refusal to acknowledge similarity.

Both the denial of difference and the denial of similarity thus lead to the same result: application of forum law, rejection of foreign law. In part, they rest on a similar attitude, namely a facile unwillingness to understand the Other, to deal with it. That unwillingness plays out in different methods, however: the lex fori approach occurs without consideration of otherness, the principled rejection of foreign law follows from an exaggeration of otherness. And although they reach the same result in the area of choice of law (because in each case forum law applies), they play out differently for the recognition of foreign judgments. Where difference is denied, foreign judgments will be recognised without any limits; where similarity is denied, foreign judgments will never be recognised.

It is necessary, therefore, to accept the other as Other in private international law, and that means: as similar and different alike. This creates a first, and important, ethical position. Paul Schiff Berman has helped explain this position, which he calls cosmopolitan, ${ }^{18}$ although it is arguably not new but really intrinsic to private international law itself. Such a position creates the discipline's proper attitude, which is one in which the possibility of deference to foreign law should be considered. But

${ }^{17}$ Michaels, R. (2016) 'Religiöse Rechte und postsäkulare Rechtsvergleichung', in R. Zimmermann (ed.), Zukunftsfragen der Rechtsvergleichung, Mohr Siebeck, 40, 53ff.

18 Berman, P. S. (2005) 'Towards a Cosmopolitan Vision of Conflict of Laws: Redefining Governmental Interests in a Global Era’, 153 U. Pa. L. Rev. 1819. 
the attitude itself does not tell us when and how such deference should take place. Something more must be involved. What should it be?

\section{Three Ethics of Private International Law ${ }^{19}$}

\section{A. An Ethic of Tolerance?}

A first ethic in private international law would be an ethic of tolerance. Tolerance certainly would offer a huge improvement over the "zero tolerance" approach the US administration has taken on its border towards refugees, ${ }^{20}$ the archetypical others to whom ethical conduct is owed. In sharp contrast, private international law can be understood as the discipline that encapsulates toleration of the other. Werner Goldschmidt based his whole private international law on the idea of tolerance; ${ }^{21}$ other authors express similar ideas. ${ }^{22}$ Benjamin Cardozo, writing for the New York Court of Appeals in 1918, expressed the attitude in a way that has become widely cited:

${ }^{19} \mathrm{H}$. Muir Watt has, in two recent publications (above fn 1), helpfully linked certain ethical positions to certain private international law doctrines. My typology is inspired by hers, although there are differences in the types I distinguish and the implications I draw for the relation between private international law and ethics.

${ }^{20}$ Office of the Attorney General, Memorandum for Federal Prosecutors Along the Southwest Border-Zero-Tolerance for Offenses Under 8 U.S.C. § 1325(a), https://www.justice.gov/opa/press-release/file/1049751.

${ }^{21}$ Goldschmidt, W. (1977) Derecho Internacional Privado. Derecho de la Tolerancia, 3d ed. Depalma, Prologue; see Oyarzábal, M. J. A. (2017) 'Goldschmidt, Werner’, in Elgar Encyclopedia of Private International Law, Edward Elgar,Vol. 1, 852, 857-58.

${ }^{22}$ See, e.g., Katzenbach, N. de B. (1956) 'Conflicts on an Unruly Horse: Reciprocal Claims and Tolerances in Interstate and International Law’, 65 Yale L.J. 1087. 
"We are not so provincial as to say that every solution of a problem is wrong because we deal with it otherwise at home.”23

Tolerance is, at first, only an attitude, but it appears also in form of a doctrine. That doctrine is comity, which the US Supreme Court once defined, tellingly, as follows:

'Comity,' in the legal sense, is neither a matter of absolute obligation, on the one hand, nor of mere courtesy and good will, upon the other. But it is the recognition which one nation allows within its territory to the legislative, executive or judicial acts of another nation, having due regard both to international duty and convenience, and to the rights of its own citizens, or of other persons who are under the protection of its laws. ${ }^{24}$

Foreign law, thus, is tolerated, though not as a matter of legal obligation but instead as a matter of "international duty and convenience.” As a consequence, the extent of this tolerance is unclear. And unclear are also the precise limits on this tolerance, which are expressed through the public policy (or ordre public) exception, which serves as a "limit of tolerance."25

${ }^{23}$ Loucks v. Standard Oil Co. of New York, 224 N.Y. 99, 111.

${ }^{24}$ Hilton v. Guyot, 159 U.S. 113, 143 (1895). For the history of comity in U.S. conflict of laws, see, most comprehensively, Dodge, W. S. (2015) 'International Comity in American Law', 115 Colum. L. Rev. 2071. For a plea to reestablish the private international law underpinnings of comity, see Childress III, D. E. (2010) 'Comity as Conflict: Resituating International Comity as Conflict of Laws', 44 U.C. Davis L. Rev. 11.

25 Struycken, A.V.M. (2004) 'Co-Ordination and Co-Operation in Respectful Disagreement', Recueil des Cours vol. 311, 9, 395. For a central role of the public 
The vagueness of both doctrines, comity and public policy, is not an accident; it is a sign of a deeper problem with understanding private international law as tolerance. Tolerance, although discussed already in antiquity, is an achievement of the enlightenment. When Locke, Bayle, and Voltaire, amongst others, write about it, what they have in mind is the treatment of religious difference. ${ }^{26}$ It thus correlates, historically, with competing truth claims. Toleration is a way to live with the other while being able to maintain the idea that the other is wrong. It is in this sense that tolerance is another word for indifference, as Somerset Maugham allegedly said. ${ }^{27}$ Indifference, in turn, is described by Karl Jaspers as "the mildest form of intolerance: secret contempt-let others believe what they like, it doesn’t concern me.”28

This idea of toleration as secret disdain can be found in private international law understood as comity and public policy: foreign law is applied not because but despite of its own value, through the forum's enlightened tolerance for what it, in principle,

policy doctrine, see also Boden, D. (2005) 'Le pluralisme juridique en droit international privé', 49 Arch. phil. droit 275-316.

26 See, generally, Forst, R. (2017), 'Toleration', The Stanford Encyclopedia of Philosophy https://plato.stanford.edu/entries/toleration/.

${ }^{27}$ The quote seems apocryphal. It does appear, however, in the Monthly Summary of the Religious Press, The Japan Weekly Mail, 14 Jan 1905, 44, at 45, where it is attributed to an article by a writer calling himself Entei in the publication Koye (Roman Catholic).

28 Jaspers, K. [1953] (2014) Origin and Goal of History, (transl. by M. Bullock), Routledge, 221. Jaspers himself distinguishes indifference from tolerance, which he defines as "open-minded: it knows its own limitations and seeks to integrate them humanly into diversity, without reducing the notions and ideas of faith to a common denominator.” Ibid. 
disagrees with. Such tolerance is therefore limited when that disagreement becomes too great. True understanding of the Other is not required and often does not take place. Where a US Court dismisses antitrust claims from Ecuadorian victims of a global cartel and defers to the regulatory interests of the Ecuadorian government, such application of comity smacks of Jasper's kind of secret disdain if the court never truly assesses what those regulatory interests are. ${ }^{29}$ And indeed, as critics of comity have often pointed out: if the foreign law is considered wrong, how can its application ever be justified? It can only be tolerated as long as it is harmless, and like the refugees at the southern border, that tolerance is withdrawn once the Other is viewed as dangerous. ${ }^{30}$

${ }^{29}$ F. Hoffman-La Roche Ltd. v. Empagran S.A., 542 U.S. 155, 165 (2004). For my critique of the Court, see Michaels, R. (2011) ‘Empagran’s Empire: International Law and Statutory Interpretation in the U.S. Supreme Court of the Twenty-First Century', in D.L. Sloss et al. (eds.) International Law in the U.S. Supreme Court: Continuity and Change, Cambridge University Press, 533. For discussion of developing nations' interests and how to accommodate them, Michaels, R. (2016) 'Supplanting Foreign Antitrust', 79 L. \& Contemp. Probs. 223.

${ }^{30}$ Cf. Treitschke, H. von (1916) Politics (transl. by B. Dugdale \& T. de Bille), Macmillan, Vol. II, 605: 'Let us make as many treaties as we like about international civil law [German original: Internationales Privatrecht, private international law], but they must all presuppose that the alien is not troublesome to ourselves. Should he become so, the State must have power to expel him without giving reasons, even if it has signed a treaty which, as a rule, ensures security of residence to the subjects of another Government.’ 


\section{B. An Ethic of Recognition?}

Goethe thought so, too: 'Tolerance should really be only a temporary attitude; it must lead to recognition. To tolerate means to offend. ${ }^{31}$ Is recognition therefore a better approach for private international law? Recognition of the Other looks, at first, like a unidirectional relation between a recognizing subject and a recognized object. However, since, Hegel, recognition is often viewed as a mutual, reciprocal process: it is through recognition of the other as an intentional person that we manage to recognise ourselves. If tolerance was the ethical position of the $18^{\text {th }}$ century, recognition was the position of the $19^{\text {th }}$ century: now, minorities—religious or otherwise-demanded more than mere toleration; they demanded to be recognised in their identity. But recognition has also become a core concern in the late $20^{\text {th }}$ century, encouraged especially through the neo-Hegelian theories of, respectively, Charles Taylor and Axel Honneth. ${ }^{32}$ Charles Taylor argues that the need for recognition is universal; the risk of its absence arises with modernity. Recognition accounts for the fact, described earlier, that the other is both similar and different: recognition accounts equal dignity to the other, but it also enables a politics of difference, in which the unique identity of the other is recognised. Axel Honneth expands such ideas to focus more on the specific relations between the

31 ‘Toleranz sollte eigentlich nur eine vorübergehende Gesinnung sein; sie muss zur Anerkennung führen. Dulden heißt Beleidigen.’ Goethe, J. W.,'Maximen und Reflexionen’, Werke XII, München 1981, 385, No. 151.

32 Taylor, C. (1992) ‘The Politics of Recognition', in C. Taylor, Multiculturalism and the Politics of Recognition, Princeton University Press, 23-73; Honneth, A. (1992) The Struggle for Recognition: The Moral Grammar of Social Conflicts, Polity Press. 
self and the other and distinguishes three: love (for self-confidence), rights (for selfrespect), and solidarity (for self-esteem).

Clearly, such ideas find responses in the law. Private international law in particular is amenable to ideas of recognition, given the central role that recognition plays for the discipline. Foreign judgments are recognised, as were, for a long time, so-called 'vested rights' established under foreign law. ${ }^{33}$ Within the EU, there is even discussion of resting an entire system of private international law on ideas of mutual recognition. ${ }^{34}$ And indeed, as in ethics, so in private international law the idea of recognition has gained much support. ${ }^{35}$

And yet, recognition is insufficient as well, both in ethics and in private international law. Nancy Fraser voices an important concern that is mirrored in private international law: the focus on recognition is insufficient for justice unless it is coupled with a focus on issues of distribution. ${ }^{36}$ We find a similar concern in private international law, in particular in the debate over the application of foreign law: how can we reconcile the

33 Dicey, A.V. (1896) A Digest of the Law of England with Reference to the Conflict of Laws, Stevens and Sons, 24-25, $28 \mathrm{ff}$.

${ }^{34}$ Lagarde, P. (ed.), (2013) La reconnaissance des situations en droit international privé, A. Pedone.

${ }^{35}$ Isailovic, I. (2016) 'La reconnaissance politique en droit transnational: Les identités, les marginalisations et le droit international privé', in E. Tourmé Jouannet, H.Muir Watt, O. Frouville \& J. Matringe (eds.), Droit international et reconnaissance, A. Pedone, 301.

${ }^{36}$ Fraser, N. (2001) 'Recognition without Ethics?', 18 Theory, Culture \& Society 2142; for the discussion with Honneth, see Fraser, N. \& Honneth. A., (2003) Redistribution or Recognition: A Political-Philosophical Exchange, Verso. 
recognition and applicability of an unjust law with our commitment to substantive justice? Jacques Rancière goes further in his critique when he questions what it is that is being recognized: the identity of the other, he suggests, does not predate the act of recognition. ${ }^{37}$ And indeed, foreign legal systems do not fully exist prior to their recognition, ${ }^{38}$ and foreign law is always applied in a way different from how it exists in the foreign system. ${ }^{39}$

Two examples demonstrate these shortcomings. When the European Court of Justice, in its Grunkin Paul decision, required German authorities to recognise a new-born's name under Danish law, it did so on the basis of a duty to recognise the child's status. ${ }^{40}$ The child is thus recognised, essentially, as having a Danish identity, as demonstrated in his name. This may be a defensible result. But does such recognition not ignore the multifaceted identity of the individual who is, as is always the case in private international law, caught between different orders? Rather than recognising a preexisting identity, it is the decision itself that constructs this identity. A second example arises from the French refusal to recognise unilateral divorces under Moroccan law as

37 See Deranty, J. P. (2003) 'Jacques Rancière's contribution to the ethics of recognition', 31 Political Theory 136; Honneth, A. \& Rancière, J. (2016), Recognition or Disagreement, Columbia University Press.

${ }^{38}$ Michaels, R. (2017) 'Law and Recognition—Towards a Relational Concept of Law', in N. Roughan \& A. Halpin (eds.), In Pursuit of Pluralist Jurisprudence, Cambridge University Press, 90-115.

${ }^{39}$ See Jansen, N. \& R. Michaels (2003) ‘Die Auslegung iund Fortbildung ausländischen Rechts’, 116 Zeitschrift für Zivilprozess , 3-56.

${ }^{40}$ ECJ, 14 October 2008, C-353-06, Grunkin and Paul. 
violating a woman's equality rights. ${ }^{41}$ The woman is here recognised as equal to the man, but in refusing to recognise her divorce, courts recreate her as a split personality: considered divorced in her country of origin (and in her faith community) yet considered married in the court's country.

Indeed, one problem of recognition can be that it goes too far: By creating identities, recognition cuts through the fluidity of the private international law individual who exists between legal systems. As a consequence, and perhaps perversely, recognition can enhance separation and thereby lead to discrimination. Elizabeth Povinelli describes such a process in the context of the recognition of aborigines in Australia: Although ostentatiously a benevolent act, the recognition actually hardens the distance between aborigines and the Australian state and confines them within their identity. ${ }^{42}$

\section{An Ethic of Hospitality?}

If tolerance is insufficient, and recognition is intrusive, the solution may lie in an ethic of hospitality. This ethic can be grounded in Martin Buber’s philosophy, as developed further by Emmanuel Levinas and Jacques Derrida. Buber suggests that the world always exists in relation to the self, but it does in two very different relations that he calls I-It and I-Thou. ${ }^{43}$ Simplified, I-It relations treat the other as an object, whereas IThou relations treat the other as a subject, as an Other. This is related to the Kantian idea of treating others as ends in themselves. But it goes beyond that because Buber's

\footnotetext{
${ }^{41}$ Fournier, P. (2016) Muslim Marriage in Western Courts: Lost in Transplantation, Routledge, 54-55 with references.

42 Povinelli, E. A. (2002) The Cunning of Recognition: Indigenous Alterities and the Making of Australian Multiculturalism, Duke University Press.

${ }^{43}$ Buber, M. (1970) I and Thou, T. \& T. Clark.
} 
focus is less on the Other and more on the relation itself. The Other is simultaneously recognized as an Other and intrinsically put in relation to the self.

This is the thought that Levinas develops further and turns into a meta-ethical position that transcends the is/ought separation: the relation itself creates a normative claim on the self. ${ }^{44}$ For Levinas, insofar like Buber, the Other is always already in a relation to me (I-Thou). But the relation is not formal and abstract: the Other comes as a concrete person with specifics (a "face"), and with concrete needs: the Other is poor, or dirty, or sick, or helpless. This Other therefore commands me through his very existence and his very needs; he demands from me: let me live. That ethical demand has priority over the ontology of the other, meaning: the Other comes to me already in an ethical relation, with a command. And I can respond to this command by following it, or not, but I cannot ignore the command.

This has surprising parallels with private international law. The foreign law already stands in a relation with the forum's law; it is never "merely there". ${ }^{45}$ That law is specific - it is not "foreign law" in the abstract, or the law of a fictitious entity like Ruritania. It has needs: it has no force in our courts, without the help of the judge who is willing to enforce it. Its command to the forum is: help me in this. Do not kill me. Do

${ }^{44}$ Levinas’ position is developed at several places, especially in his Levinas, E. (1961) Totality and Infinity, Kluwer. For helpful introductions, see E. Levinas (1995) Ethics and Infinity-Conversations with Philippe Nemo, Duquesne University Press; Morgan, M. L. (2011) The Cambridge Introduction to Emmanuel Levinas, Cambridge University Press, ch. 3 'The Ethical Content of the Face-to-Face', 59ff.

${ }^{45}$ Michaels, R. (2017), 'Law and Recognition. Towards a Relational Concept of Law' (fn 38). 
not be jurispathic, to use Robert Cover's term. ${ }^{46}$ And so the forum can yield to this command or not, but it cannot escape it.

Take, for example, partners in a same-sex marriage celebrated elsewhere, asking for recognition of their marriage. The marriage under foreign law is part of their identity, the plea for recognition is clear (and, where the status of being married can prevent deportation, it is literally a plea to save their lives) ${ }^{47}$. Now the court cannot escape the demand: even if it denies the claim for recognition, it cannot thereby avoid the relation. ${ }^{48}$

Horatia Muir Watt, drawing on Derrida (who was in this respect influenced by Levinas) has demonstrated how such thoughts can inform an understanding of private international law. ${ }^{49}$ Traditional private international law, she suggests, recognises foreign law merely under certain conditions, namely a certain level of similarity; it is based only on ideas of tolerance. Hospitality as unconditional acceptance, by contrast, can be found in unilateral approaches to private international law. Here, the foreign law

${ }^{46}$ Cover, R.M. (1983) 'The Supreme Court, 1982 Term’ Foreword: Nomos and Narrative, 97 Harv. L. Rev. 4, 40 ff.

${ }^{47}$ Jessurun d'Oliveira, H. U. (1999), 'The Artifact of "Sham Marriages”, 1 Yearbook of Private International Law, 49-83.

${ }^{48}$ See Cossman, B. (2008) 'Betwixt and Between Recognition: Migrating Same-Sex Marriages and the Turn Toward the Private', 71 L. \& Contemp. Probs., 153-168.

${ }^{49}$ Politics of Difference, above fn 1. Muir Watt (2017) draws on J. Derrida (2000), Of Hospitality-Anne Dufourmantelle invites Jacques Derrida to Respond, Stanford University Press; see also J. Derrida, (2001) Cosmopolitanism and Forgiveness, Routledge. Levinas' influence on Derrida's concept of hospitality, palpable throughout both texts, becomes even clearer in J. Derrida, (1999) Adieu to Emmanuel Levinas, Stanford University Press. 
necessarily appears in its concrete specificity and gets applied because it wants (needs) to be applied according to the doctrine of unilateralism. Unilateralism is often rejected in private international law as an is/ought crossover: the fact that the foreign law wants to be applied (a fact) has no normative implication that the forum should apply it. ${ }^{50} \mathrm{~A}$ response can invoke Levinas: the mere fact that the foreign law appears related to us, in its specificity, and with its needs (in this case: to be applied) creates an ethical plea for such application, but not yet more. The is/ought crossover is not the only criticism of unilateralism, however. The bigger problem is, arguably, that unilateralism is too powerful: by ceding to the other entirely, we give foreign law more force than domestic law. The US Supreme Court once discussed this possibility as absurd: “A rigid and literal enforcement of the full faith and credit clause, without regard to the statute of the forum, would lead to the absurd result that, wherever the conflict arises, the statute of each state must be enforced in the courts of the other, but cannot be in its own." ${ }^{51}$ Muir Watt suggests that this is not an insoluble problem: applicability of foreign law is not unlimited but instead remains under control of the public policy exception. ${ }^{52}$ But this seems incompatible with the idea she draws on. Derrida in particular suggests that hospitality is not only unconditional but also unlimited; it requires to receive the stranger not just without any conditions (of similarity, even of giving her name), but also without any limitations: the host is required to offer literally everything: his house,

50 Schurig, K. (1986) 'Lois d'application immediate und Sonderanknüpfung zwingenden Rechts: Erkenntnisfortschritt oder Mystifikation?', in W. Holl and Klinke. U. (eds), Internationales Privatrecht-Internationales Wirtschaftsrecht, 55.

${ }^{51}$ Alaska Packers Ass'n v. Industrial Accident Commission of California, 294 U.S. 532, 547 (1935).

${ }^{52}$ Muir Watt (2017), 'Politics of Difference', above fn 1, at 138. 
his wealth, his family. Such absolute hospitality is an impossibility, while Muir Watt's restriction is possible. At the same time, hospitality limited by a public policy exception is no longer hospitality in the sense of Derrida; at its core it is again merely limited deference.

\section{An Ethic of Responsivity}

\section{A. The Focus on Relation}

What then should an ethical approach to private international law look like? Some progress has been made. In part I, I demonstrated that the ethical relevance of private international law lies in its focus on the other, and that it must recognise the other as both similar and different, as both independent and related. That created an attitude of a principled willingness to defer to foreign law, but not more. In part II, I discussed different ethical positions towards the other—-tolerance, recognition, hospitality—and related these to different approaches to private international law. These positions describe different degrees of willingness to defer to foreign law, as Muir Watt describes in her somewhat parallel project: apply foreign law never, sometimes, always. ${ }^{53}$ Different ethical positions do not, however, only differ in the degree of deference to the foreign. They also differ in the kind of relation they construct. Tolerance creates a relation of wilful ignorance; recognition creates a relation of hierarchy; hospitality rests on a relationship of need.

And the positions differ in the degree to which they view the other as independent from that relation. Tolerance assumes the other to be independent, though it may require the

\footnotetext{
${ }^{53}$ Muir Watt (2017), 'Politics of Difference', above fn 1, at 115, 126.
} 
other to become more similar in order to justify being tolerated. Comity can be remarkably blind for the actual content of the foreign law. Recognition is more ambivalent: insofar as it is the act of recognition that constructs the other, recognition becomes a violent act, one that defines the other. Povinelli's example, discussed before, comes to mind. Hospitality, finally, is the ethical position that positions the relation as irreducibly linked to the other: the other appears only in relation (Buber), and that relation is ethical before it is ontological (Levinas).

This suggests that it is worthwhile to shift the gaze from the Other to the relation in which the self stands to the Other, from the foreign law as such to the relation in which that foreign law stands to the forum. What is lacking here is a finer analysis of what exactly that relation entails. Both a plea for survival (Levinas) and unlimited hospitality (Derrida) are in themselves insufficient: mere survival is too minimal, unlimited hospitality is too maximal. Both can generate discussions about concrete ethical problems, but they do not entail them through logical deduction. Once we focus on the relation we no longer ask what is owed to the foreign law; instead we ask what the relation entails.

\section{B. The Relevance of Technique}

This is where technique becomes relevant. After all, in private international law we do not confine ourselves to a two-step analysis, in which we first define a deferential relation to the Other and then limit it through the public policy exception. Instead, the relation to the Other is established through a number of devices that are used in the analysis of private international law: characterization, renvoi, adaptation, substitution, public policy, etc. These devices, which are 'merely technical,' are often thought of as anathema to questions of ethics. At best, they are insufficient devices to avoid outcomes 
that are normatively undesirable - the US debate speaks in this context of 'escape devices. ${ }^{54}$ At worst, they are devices that blind the analyst for the actual ethical relevance in the case-this is what the European reception of the US conflicts revolution emphasised, and what new critical approaches to private international law re-establish. ${ }^{55}$

Technique is often thought to be merely that: opposed to theory and opposed to ethics. Muir Watt suggests, apodictically: “Often described as 'theoretical', these aspects of private international law are essentially technical and have little relationship with the great questions of legal theory." 56 This may be true for the practical application of private international law, but it seems untrue for the field in general. Justice Frankfurter referred to Joseph Beale's conflict of laws course as a course in jurisprudence, and Beale was arguably the most technical of conflicts scholars in the US. ${ }^{57}$ It is not only

${ }^{54}$ Currie, B. (1959) 'Notes on Methods and Objectives in the Conflict of Laws', Duke LJ, 171, 175.

${ }^{55}$ Muir Watt (2011), 'Private International Law Beyond the Schism’ above fn 13. ${ }^{56}$ Ibid. at 380, fn 163.

${ }^{57}$ Frankfurter, F. (1943) 'Henry Joseph Beale', 56 Harv. L. Rev., 701, 703. Beale is almost universally rejected today; see only Symeonides, S. (2007) 'The First Conflicts Restatement through the Eyes of Old: As Bad as its Reputation?', 32 Southern Ill LR, 39. See also Freund, Paul A., (1946) 'Chief Justice Stone and the Conflict of Laws', 59 Harv. L. Rev., 1210, 1210: 'Chief Justice Stone ... would regard Conflict of Laws as a study serving in place of a course in Jurisprudence', with cite to the passage by Frankfurter. 
the case that private international law provides fruitful inspirations for legal theory. ${ }^{58}$ It is also the case that private international law can itself be viewed as a legal theory, and that its technical devices do not avoid difficult questions of politics and ethics but instead serve to formulate them in a way that is more prone to allowing responses. ${ }^{59}$

The theoretical and ethical content of the techniques of private international law cannot here be demonstrated with sufficient specificity. Two examples must suffice. The first concerns the application of foreign law itself. ${ }^{60}$ True deference to foreign law puts the judge before an ethical dilemma: Respect for the foreign law requires the judge on the one hand to get foreign law right and on the other hand to realise that she is not a part of the foreign law and can therefore not make authoritative claims to its meaning. The discipline of anthropology has, for the parallel problem that truly "going native" is impossible, developed the device of "lateral thinking": thinking through the other, thinking 'as if' one were part of the other. ${ }^{61}$ In private international law, the "foreign court theory" according to which a judge is supposed to apply foreign law 'as if' she were sitting in the foreign court, takes a similar move. The foreign court theory must

${ }^{58}$ Maurer, A. \& M. Renner (2010) 'Kollisionsrechtliches Denken in der Rechtstheorie' in: Konflikte im Recht-Recht der Konflikte 125 Archiv für Rechts- und Sozialphilosophie 207-24.

${ }^{59}$ Or so I have argued: Michaels, R. (2014) 'Post-Critical Private International Law: From Politics to Technique', in D. P. Fernández Arroyo and H. Muir Watt (eds.), Private International Law and Global Governance, Oxford University Press, 54-67.

${ }^{60}$ For the following, see Riles, A. (2008) 'Cultural Conflicts', 71 L. \& Contemp. Probs., 273, 296ff.

${ }^{61}$ For a summary, see Gad, C. \& C. B. Jensen, (2016) 'Lateral Concepts', 2 Engaging Science, Technology, and Society 3-12. 
then be seen not as an impossibility but instead as a sophisticated and attractive ethical move.

Or take the aforementioned public policy exception. It is the response to another ethical dilemma: the conflict between the duty of deferring to foreign law and the duty to avoid the application of a law that is incompatible with fundamental values. The public policy exception actually responds in a very subtle way to minimise the conflict. First, it is directed not against the foreign law itself but only against the result of its application in the forum state. Second, the standard of review is not some supposed universal set of values, but instead the values of the forum state. Third, the public policy exception only sets in when there are sufficient connections to the forum state. All of this is like saying to the Other: I respect you, I do not question your identity, and I do not suggest that my values are better than yours merely because they are mine. I merely minimise the impact of your identity insofar as it fundamentally upsets my home. And I do so because, in this concrete case, my home is so directly affected, because of the strong relationship between the conduct and my home. Seen like this, the public policy exception is not merely the ethical stop gap against the mechanical application of foreign law; it is itself a deeply ethical device.

Note what role ethics plays here. Ethics does not come before the devices of private international law, as a normative foundation to inform them. Nor does ethics come after them, as an ex post tool to evaluate their quality. Instead, ethics is within these devices themselves. These technical devices are themselves ethical constructions: it is through private international law itself that an ethical position is formulated and at the same time put into practice. This is what it means to understand private international law as an ethic, not merely as grounded in one. 


\section{An Ethic of Responsivity}

Finally, what kind of an ethic is it? The technique of private international is not merely a device of fine-tuning comity to determine the exact border between deference and its limits. Instead, the technique of private international law is an ethic of a particular nature: it is, to borrow a concept from Bernhard Waldenfels, an ethic of responsivity. ${ }^{62}$ Responsivity is different from both intentionality and regularity: "that with which I respond owes its meaning to the challenge to which it responds." 63 Through the application of complicated technique vis-à-vis the foreign law, private international law takes the Other more seriously than mere deference would. Application of private international law rules is never purely mechanical; it always operates in response to the concrete other law, and therefore private international law is always necessarily open. ${ }^{64}$ Thereby, private international law engages the Other. It takes the Other's plea more seriously than mere deference would. It grapples with the Other. It puts the positions taken by the Other in perspective and in context. It creates a hypothetical dialogue with the Other-hypothetical because the dialogue takes place within private international

${ }^{62}$ See Waldenfels, B. (2003) 'From Intentionality to Responsivity’, in R. Bernet \& D. J. Martino (eds.), Phenomenology Today: The Schuwer Spep Lectures, 1998-2002, 2335; Waldenfels (2007), above fn 14, at 21ff.; Leistle, B. (2016), 'Responsivity and (some) other approaches to alterity', Anthropological Theory Vol. 16(1) 48-74. Waldenfels distinguishes responsivity as a creative process from technical responses as results from a program: Waldenfels, B. (2015) Sozialität und Alterität-Modi sozialer Erfahrung, Suhrkamp, 18-19. My use of technique encompasses the creativity, which is arguably always present in the process of private international law.

${ }^{63}$ Waldenfels (2003), above fn 62, at 24.

${ }^{64}$ Schurig, K. (1981) Kollisionsnorm und Sachrecht. Zu Struktur, Standort und Methode des internationalen Privatrechts, Duncker \& Humblot, 170-176. 
law's own position, ${ }^{65}$ but therefore no less real. The response can lead to a result that a conflict remains, just as in conflicts among individuals the ethically required result is sometimes that the conflict remains. Responsivity does not merely equate deference. But responsivity makes rejection justifiable.

Private international law can act as an ethic of responsivity because it is not a merely theoretical position. It shares that emphasis on practice with existing positions in the discipline of ethics. It is, then, a practical ethic, but one of a specific kind because its practice consists of legal doctrine, in a particular kind of technical argument. Where the Other is a legal order, legal doctrine becomes the practice to which private international law responds: the Other is law, the relation to it is law, and the ethic that emerges from that is law, too.

\section{Conclusion}

I have argued that private international law not only has ethical relevance, but that it is itself an ethic, namely an ethic of responsivity. That ethic relies on three foundational building blocks, discussed in three sections: the Other, the relation to the Other, and the technique of responsivity. The two first blocks exist in ethics more generally. The third is specific to private international law, simply because the technique of private international law is specific to private international law. The first two blocks do not need private international law. The third one is private international law's own contribution to ethics.

${ }^{65}$ See Knop et al. (2012) above fn. 4, at 648-49. 
What follows for the way in which we engage in private international law? If we feel that private international law is of ethical importance-and how could we not? - then the findings here should be reason for hope. The hope is that the relation to the Other, that hugely important ethical issue of our times, can find an adequate ethical response, although in an unexpected place. Private international law, understood as an ethic, is not a mere technical device that leads to arbitrary responses. Nor is it a field that needs to be completely reinvented in order to be ethically relevant. What is necessary is to understand that, and how, private international law itself operates as an ethic, and that it does so through its technique.

That in itself is not a small step. It does not require a radical reinvention of the field, but it requires a fairly radical reorientation of our thinking of the field. To know that we are, when we apply doctrines of private international law, operating in ethical theory and practice, is empowering, but it also creates a great responsibility. Private international law, far from being at the margin of the big issues of our world, stands in its centre. The biggest ethical issues of our world require us to define our relation to the Other. Let us see how private international law as an ethic of responsivity can do this. 